JOSETA: Journal of Socio Economic on Tropical Agriculture

Volume 1 Nomor 1: 71-78 April (2019)

JOSETA: Journal of Socio Economic on Tropical Agriculture http://joseta.faperta.unand.ac.id

ISSN : $2686-0953$ (online)

\title{
ANALISIS USAHA PENGOLAHAN SALAK PADA UKM SALACCA DI KABUPATEN TAPANULI SELATAN PROVINSI SUMATRA UTARA
}

\author{
The Business Analysis of Snake Fruit Processing on UKM Salacca in South Tapanuli Regency
}

North Sumatera

\author{
Nur Jannah ${ }^{1}$, Syahyana Raesi ${ }^{2}$, Syofyan Fairuzi ${ }^{3}$ \\ ${ }^{1}$ Jurusan Sosial Ekonomi Fakultas Pertanian Unand, Padang, indonesia \\ *raesi_s@yahoo.com \\ Received: $20^{\text {th }}$ Februari, 2019; $1^{\text {st }}$ Revision: $10^{\text {th }}$ Maret, 2019; Accepted: $19^{\text {th }}$ April, 2019
}

\begin{abstract}
Abstrak
Penelitian ini bertujuan untuk mendiskripsikan profil usaha pengolahan salak UKM Salacca dan menganalisis kondisi UKM Salacca dari aspek operasional, aspek pemasaran, dan aspek keuangan dan mengetahui keuntungan serta titik impas usaha. Penelitian menggunakan metode deskriptif dengan jenis penelitian studi kasus dengan perhitungan keuangan menggunakan metode variable costing. Data yang digunakan adalah data primer dan sekunder.Pengumpulan data dengan melakukan wawancara dan literatur. UKM Salacca hanya melakukan pencatatan sederhana. Keuntungan yang diperoleh UKM Salacca selama 1 bulan periode penelitian pada bulan Mei 2018 sebesar Rp 16.568.483,-. Keuntungan paling tinggi adalah Dodol salak sebesar Rp 7.212.542,--Titik impas usaha selama periode penelitian pada bulan Mei 2018, impas penjualan Dodol salak sebesar Rp 10.833.430,- Kurma salak Rp 5.919.880,- dan Keripik salak Rp 4.844.260,-. UKM Salacca sudah berproduksi diatas titik impas dan mencapai keuntungan sebesar 32\%. Saran yang diberikan kepada pihak usaha adalah UKM salacca dapat memperluas kerjasama dalam memasarkan produknya, menambah tenaga kerja dan peralatan agar efektif dan efisien, melakukan pencatatan yang lebih baik dan lebih rinci terkait biaya-biaya dan pendapatan penjualan yang dikeluarkan selama proses produksi.
\end{abstract}

Kata kunci : UKM, keuntungan, titik impas

\begin{abstract}
The research aims to analyze : study of processed salak fruit of ukm salacca in padang sidimpuan. The purpuse of thos study was to assess the condition of ukm salacca consists of operational, marketing, financial, profit analyze and break event point. The analyze methods of this research is descriptive methods. The types of research is case study and the financial analyze with variable costing methods. Data types consisted of primary data and secondary data. The data collection techniques were interviews and literature. The result showed, the profit obtained monthly Rp. 16.568.483,- on Mei 2018 and the highest revenue came from snake fruit palm which was $R p$ 7.212.542,-. Meanwhile business breakeven points during the research period for snake fruit taffy was $R p$ 10.883.430,- snake fruit palm was $R p$ 5.919.880,- and snake fruit chip was $R p$ 4.844.260,-. UKM Salacca have produced above the breakeven point and achieved a profit of $32 \%$.
\end{abstract}

Keywords :UKM, profit, breakeven

\section{PENDAHULUAN}

Hortikultura merupakan salah satu komoditi andalan sektor pertanian di Indonesia. Komoditi hortikultura yang banyak dikembangkan di Indonesia antara lain buah-buahan, sayuran dan aneka 
tanaman hias. Salah satu komoditi tanaman hortikultura yang dapat diolah dan memberikan nilai tambah adalah salak.

Pengolahan buah salak merupakan cara untuk mengatasi kelimpahan di sentra produksi ketika panen raya dan tidak dapat terserap semua untuk konsumsi segar. Usaha pengolahan salak menjadi produk turunan seperti dodol salak,kurma salak, kripik salak,minuman salak,sirup salak dan produk turunan lainnya dapat ditemukan di daerah Kabupaten Tapanuli Selatan yang dimanfaatkan masyarakat untuk meningkatkan nilai tambah salak, membuat produk menjadi lebih tahan lama dan memberikan keuntungan. Pendekatan pembangunan yang ditujukan pada pelaku ekonomi, khususnya pada koperasi dan UMKM sangat penting. Dengan memperhatikan peran dan potensinya dalam perekonomian nasional, keberadaan koperasi dan UMKM terbukti merupakan pelaku usaha yang mandiri, kokoh dan fleksibel, dalam kondisi normal maupun krisis sekalipun. Bahkan tidak dapat disangkal oleh siapapun bahwa koperasi dan UMKM merupakan leader perekonomian Indonesia. Koperasi dan UMKM menjadi jantung ekonomi rakyat, dan pelopor tumbuhnya ekonomi kerakyatan (Kementerian Koperasi dan UKM, 2010).

Analisis usaha menurut Rahardi,dkk (2007), setiap pengusaha yang menjalankan kegiatan usahanya tentu mengharapkan agar usahanya dapat memperoleh keuntungan yang besar serta adanya keberlanjutan usaha. Untuk itu,dibutuhkan analisis usaha agar usaha tersebut dapat mengetahui tingkat keuntungan yang dapat diperolehnya serta memberikan gambaran untuk melakukan perencanaan jangka panjang. Analisis usaha juga dapat membantu mengetahui dan mengatasi permasalahan yang dihadapi oleh sebuah usaha, sehingga usaha dapat berjalan dengan baik dan adanya kemungkinan untuk melakukan pengembangan usaha.Oleh karena itu penting dilakukan penelitian tentang analisis usaha agar usaha tersebut dapat mengetahui tingkat keuntungan yang dapat diperolehnya serta memberikan gambaran untuk melakukan perencanaan jangka panjang.

Hasil analisis usaha dapat memprediksi kemungkinan perkembangan usahanya, menentukan efektif atau tidaknya saluran distribusi produk yang telah dilakukan serta dapat mengidentifikasi biaya-biaya yang dikeluarkan untuk produksi yang pada akhirnya dapat menentukan harga pokok produksi dan dapat menetapkan harga jual yang tepat sehingga usaha dapat memperoleh keuntungan.Analisis usaha juga dapat mengetahui dan mengatasi masalah yang dihadapi dalam usaha tersebut, dengan diatasinya masalah tersebut maka pemilik dapat memaksimalkan jumlah produksi, menghasilkan produk yang berkualitas, serta dapat meminimalkan penggunaan biaya sehingga kegiatan usaha dapat berjalan dengan efisien.Oleh sebab itu, penelitian tentang analisis usaha pada sebuah industri yang berguna untuk mengetahui bagaimana keadaan atau kondisi laba rugi pada usahanya penting untuk dilakukan.

\section{RUMUSAN MASALAH}

Usaha Salacca merupakan usaha yang didirikan oleh Ibu Sry Lestari SHi, MEi.Usaha ini bergerak dalam bidang agroindustri di Kabupaten Tapanuli Selatan yang khusus memproduksi produk olahan salak.Keberadaan usaha ini memberikan nilai tambah pada komoditi salak, dimana daerah Kecamatan Angkola Barat ini merupakan penghasil buah Salak terbesar serta dapat menjadi sumber pendapatan bagi tenaga kerja usaha tersebut. Produk olahan yang dihasilkan usaha ini bervariasi seperti dodol salak, kurma salak, sirup salak, kripik salak, agar-agar salak, kopi salak, kecap salak, dan minuman salak dengan menggunakan bahan baku varietas salak Padang Sidempuan.

Dalam menjalankan usahanya UKM Salacca masih mengalami berbagai kendala seperti pada aspek produksi yaitu pengadaan bahan baku dan bahan penolong dimana harga dari setiap bahan selalu mengalami perubahan seiring dengan harga pasar. Akibat dari kenaikan harga bahan baku yang berkisar dari Rp 3.000 - Rp 4.000 per kg dan bahan penolong, pemilik usaha tidak dapat langsung menaikan harga jual produknya karena toko tempat produk Salacca dipasarkan belum dapat menerima harga yang ditawarkan oleh usaha Salacca. Dari awal berdiri sampai sekarang UKM Salacca tidak pernah menaikkan harga jual produknya. Masing -masing harga untuk produk dodol salak Rp 13000/ kotak, Kurma salak Rp 11.000/ kotak sedangkan untuk keripik salak Rp 13.000/ kotak Usaha Salacca masih berada pada skala usaha kecil, berproduksi berdasarkan permintaan dan permintan tersebut selalu berflutuasi. Saat ini, UKM Salacca hanya mengandalkan keuntungan dari usaha untuk mempertahankan dan mengembangkan usahanya.Selain itu, belum adanya perencanaan keuangan dan prosedur penganggaran yang efektif dan efisien sehingga penganggaran dilakukan berdasarkan intuisi dari pemilik usaha UKM Salacca.

https://doi.org/10.25077/joseta.v1i1.187 
Dalam aspek keuangan, Pemimpin usaha Salacca ini masih belum melakukan perencanaan keuangan dalam menjalankan kegiatan usahanya, sejak awal berdiri tidak pernah menerapkan prinsip akuntansi dalam pencatatan keuangan, pemilik usaha hanya menggunakan daya ingat dan sedikit catatan kecil untuk menunjang kebijakan yang diambilnya.

Semua keputusan yang berkaitan dengan hasil produksi, pencatatan keuangan dan pemasaran produk masih belum dicatat dengan baik. Mengingat prospek pengembangan usaha kecil ini cukup menjanjikan dimasa depan, maka selain tingkat keuntungan usaha, juga perlu dianalisis aspek manajemen operasi, aspek keuangan dan aspek pemasaran pada usaha tersebut. Selain itu, Break Event Point (BEP) juga sangat perlu dianalisis agar dapat memberikan gambaran tentang batas jumlah penjualan produk olahan salak minimal agar usaha Salacca tidak mengalami kerugian.

\section{TUJUAN PENELITIAN}

Berdasarkan rumusan masalah diatas, tujuan penelitian yang ingin dicapai yaitu:

1. Mendiskripsikan usaha yang dilakukan oleh UKM Salacca di kabupaten tapanuli selatan provinsi sumatera utara

2. Menganalisis besarnya keuntungan dan titik impas usaha pengolahan salak pada UKM Salacca di Kabupaten Tapanuli Selatan Provinsi Sumatera Utara

\section{METODE PENELITIAN}

1. Metode Deskriptif deskriptif dengan jenis penelitian studi kasus (case study).

Metode deskriptif adalah suatu metode yang meneliti status kelompok manusia, suatu objek, suatu set kondisi, suatu sistem pemikiran, ataupun suatu kelas peristiwa dengan tujuan membuat gambaran atau deskripsi mengenai situasi atau kejadian secara sistematis, factual, akurat mengenai fakta-fakta, sifat-sifat serta hubungan antar fenomena yang terjadi (Nazir, 2011). Jenis penelitian studi kasus merupakan jenis penelitian dari metode deskriptif yang memberikan gambaran secara mendetail tentang latar belakang, sifat-sifat serta karakter-karakter yang khas dari kasus, ataupun status individu , yang kemudian dari sifatsifat khas tersebut akan dijadikan suatu hal yang bersifat umum (Nazir, 2011).

2. Metode Pengumpulan Data

Pengumpulan data dalam penelitian ini menggunakan teknik observasi langsung, wawancara langsung dengan pihak yang terkait, dan studi literatur.

1. Observasi langsung, yaitu melakukan pengamatan langsung pada usaha Salacca mengenai kegiatan usaha yang dilakukan dan hal-hal lainnya yang mendukung penelitian.

2. Wawancara langsung dengan pihak yang terkait, yaitu melakukan proses tanya jawab dengan beberapa pihak yang terkait, yaitu dengan percakapan dua arah yang dilakukan untuk memperoleh informasi dari informan kunci. Informan kunci ini terdiri dari: pemilik usaha dan tenaga kerja bagian produksi.

3. Jenis dan Sumber Data

Data yang dikumpulkan adalah data primer dan data sekunder yang berhubungan dengan persoalan penelitian.

Menurut (Nazir, 2011), data primer adalah data dari sumber-sumber dasar yang merupakan bukti dari kejadian yang lalu, data primer diperoleh melalui hasil observasi, wawancara langsung dengan informan kunci pada usaha yang bersangkutan dengan menggunakan panduan wawancara yang dipersiapkan dari pengamatan langsung dilapangan.

Data sekunder adalah data berbentuk tulisan atau dokumen yang berhubungan dengan permasalahan penelitian yang diperoleh dari instansi-instansi terkait dalam penelitian, antara lain Badan Pusat Statistik Kabupaten Tapanuli Selatan, Dinas Perindustrian dan Perdagangan Kabupaten Tapanuli Selatan, Dinas Kesehatan Tapanuli Selatan, serta data lainnya yang diperoleh dari literatur yang relevan seperti hasil 
penelitian dan buku-buku pustaka lainnya yang relevan dengan penelitian. Selain itu, data sekunder diperoleh melalui browsinginternet guna mencari artikel dan data lainnya yang mendukung penelitian.

4. Analisis Data

Untuk tujuan pertama dianalis dengan menggunakan analisis diskriptif kualitatif dimana untuk menggambarkan dan mengguraikan profil usaha dari aspek produksi, pemasaran ,keuangan dan sumber daya dari usaha Salacca. Untuk tujuan kedua menganalisis keuntungan usaha dan titik impas dilakukan analisis kuantitatif digunakan pendekatan metode variable costing . dimana

Laba bersih $=$ Pendapatan penjualan - Biaya Total $(1)$

Untuk titik impas

BEP dalam satuan bungkus

$\mathrm{BEP}=$ Total Biaya Tetap $(\mathrm{Rp} / \mathrm{bl})$

Harga jual (Rp/Bks) - Biaya Variabel (Rp/Bks)

BEP dalam satuan rupiah

$\mathrm{BEP}=$ Total Biaya Tetap $(\mathrm{Rp} / \mathrm{bulan})$

Biaya variabel (Rp/bulan)

$1-$

Harga Jual (Rp/bks)

\section{HASIL DAN PEMBAHASAN}

\section{Gambaran Umum Usaha}

UKM Salacca adalah salah satu usaha agroindustri pengolahan buah salak yang ada di Tapanuli Selatan.Usaha yang didirikan oleh Ibu Sri Lestari SHi, MEi Ini merupakan usaha perseorangan. Ibu Sri Lestari SHi, MEi bertindak sebagai pimpinan dan bendahara dalam UKM Salacca. Usaha Salacca beralamat di Jalan Sibolga Km.11 Aek Nabara Parsalakan Kecamatan Angkola Barat Kabupaten Tapanuli Selatan Provinsi Sumatera Utara.

Usaha ini didirikan pada tahun 2014, dimana pemilik mulai membangun tempat usahanya sendiri. Latar belakang berdirinya UKM Salacca karena untuk memberikan nilai tambah pada buah salak yang melimpah dan lebih mengenalkan buah salak kepada daerah lain yang merupakan ciri khas dari Tapanuli selatan ini sendiri dan juga adanya keinginan dari pemilik usaha untuk mempunyai usaha sendiri dan untuk menambah pendapatan keluarga.

\section{a.Aspek Sumber Daya Manusia}

UKM Salacca ini memiliki 11 orang tenaga kerja yang terdiri dari 1 orang pimpinan usaha yang merangkap sebagai tenaga kerja bagian administrasi dan keuangan.Pada bagian produksi terdapat 7 orang tenaga kerja dan 2 orang bagian pengemasan.Sedangkan 1 orang bekerja di bagian pemasaran. Sesuai dengan fungsinya, pada dasarnya di dalam perusahaan terdapat dua macam tenaga kerja (Swastha dan Sukotjo, 2007), yakni : (a) Tenaga Eksekutif : yang mempunyai dua tugas pokok ialah mengambil berbagai keputusan dan melaksanakan fungsi organik manajemen : merencanakan, mengorganisasi, mengarahkan, mengkoordinir dan mengawasi dan (b) Tenaga Operatif : merupakan tenaga terampil, yang menguasai bidang pekerjaannya, sehingga setiap tugas yang dibebankan kepadanya dapat dilaksanakan dengan baik. 
Berdasarkan metode yang digunakan perusahaan dalam hal pemberian upah dapat disimpulkan bahwa penetapan upah pimpinan dan tenaga kerja bagian produksi, pengemasan dan pemasaran ditetapkan dengan metode Gaji (Wage) yang dibayarkan setiap bulannya.

Dalam proses produksi UKM Salacca telah menggunakan mesin serta peralatan yang memudahkan UKM Salacca dalam melakukan kegiatan produksi, sehingga berdampak pada produktivitas dan kualitas produk yang dihasilkan. Penggunaan mesin dan peralatan yang mendukung proses produksi tersebut akan mengeluarkan biaya penyusutan. Nilai penyusutan dari jenis-jenis peralatan dan investasi ini berbeda satu sama lain karena dipengaruhi oleh harga beli, nilai sisa peralatan, dan umur ekonomisnya yang dihitung menggunakan metode garis lurus (straight-line). Pada metode ini, nilai penyusutan yang dikeluarkan bernilai tetap untuk setiap tahun penggunaan peralatan. Sedangkan untuk nilai penyusutan akan makin menurun dari tahun ke tahun. Total penyusutan peralatan pada UKM Salacca ini adalah sebesar Rp $1.151 .640,-$.

\section{b.Aspek pemasaran}

UKM Salacca dalam memasarkan produknya, pemilik menjalin kerjasama dengan beberapa outlet seperti toko oleh-oleh, swalayan, maupun pedagang pengecer Produk olahan salak UKM Salacca baik itu dodol salak, kurma salak dan keripik salak termasuk dalam produk konsumsi karena pembeli merupakan konsumen akhir dan bukan sebagai pemakai industri. Kualitas dari produk Salacca memilih produk bahan baku pilihan yang segar sehinngga kualitas yang dihasilkan juga bagus. UKM Salacca memberi merk yang berbeda-beda pada tiap produknya, yang diambil dari bahasa Batak Angkola Kabupaten Tapanuli Selatan dan bahasa inggris.

Untuk dodol salak dan kurma salak menngunakan kotak yang berbahan dasar kertas dengan ukuran $15 \times 10 \mathrm{~cm}$ dengan tebal $3 \mathrm{~cm}$ namun desain yang berbeda dengan isi ukuran 300 gr. Untuk keripik salak dan kurma salak menggunakan kotak yang juga berbahan dasar kertas dengan ukuran $15 \times 10 \mathrm{~cm}$ dengan isi ukuran 100 gr dan 200 gr. Produk UKM Salacca memiliki harga jual yang berbeda-beda tergantung dari jenis produknya sendiri, untuk dodol salak dan keripik salak salak dijual dengan harga Rp. 13.000,/kotak, untuk kurma salak dijual dengan harga Rp. 11.000,-/kotak.

Pemasaran produk yang dilakukan UKM Salacca ini yaitu dengan menggunakan saluran distribusi langsung dan distribusi tidak langsung (campuran). Pada saluran pertama (1), konsumen akhir membeli produk olahan salak dari tempat produksi, biasanya konsumen yang tinggal di sekitar lokasi usaha ataupun konsumen yang hanya lewat kemudian singgah untuk membeli produk olahan salak sebagai oleholeh sebesar $28 \%$. Pada saluran kedua (2), pedagang pengecer yang datang langsung membeli ke tempat produksi ataupun UKM Salacca yang akan mengantarkan dan mengirim produk ke pedagang pengecer kemudian menjualkannya kepada konsumen akhir sebesar $72 \%$.

\section{c.Aspek Keuangan}

Modal awal untuk mendirikan UKM Salacca ini didapat dari modal sendiri yaitu sebesar Rp. 50.000.000,- yang digunakan untuk kegiatan usaha pengolahan salak yaitu untuk modal operasional seperti pembelian alat-alat dan kegiatan produksi. Berdasarkan penelitian yang telah dilakukan, UKM Salacca ini mengalokasikan dana usahanya untuk penggunaan jangka pendek dengan melihat kemampuan membayar kebutuhan usaha sehari-sehari. Selain itu, usaha ini juga telah mengalokasikan dana modal usahanya untuk jangka panjang dan ingin membeli mesin dan peralatan yang menunjang kegiatan usaha. Berdasarkan penelitian yang telah dilakukan, pihak usaha hanya melakukan pencatatan yang sederhana dalam mengatur keuangan perusahaan.Pihak usaha belum melakukan pencatatan secara khusus, yang memuat segala jenis kegiatan dan transaksi yang terjadi.

\section{Analisis Usaha}

a. Pendapatan dan Keuntungan

Pendapatan penjualan yang dihasilkan dodol salak selama periode penelitian adalah sebesar Rp 24.843.000,-, sementara yang dihasilkan kurma salak selama periode penelitian adalah sebesar Rp 
15.257.000,-,dan Pendapatan penjualan yang dihasilkan keripik salak selama periode penelitian adalah sebesar Rp 10.803.000,-. Laporan laba rugi UKM salacca dapat dilihat pada tabel 1 dibawah berikut

Tabel 1.Laporan laba rugi UKM salacca

\begin{tabular}{|c|c|c|c|c|}
\hline Keterangan & Dodol Salak (Rp) & Kurma Salak (Rp) & Keripik Salak (Rp) & Total (Rp) \\
\hline Pendapatan Penjualan & 24.843 .000 & 15.257 .000 & 10.803 .000 & 50.903 .000 \\
\hline \multicolumn{5}{|l|}{ Biaya Variabel } \\
\hline Biaya Bahan Baku & 5.563 .213 & 3.029 .758 & 2.879 .055 & 11.472 .026 \\
\hline \multicolumn{5}{|l|}{ BOP Variabel : } \\
\hline Biaya Bahan Penolong & 4.716 .629 & 254.971 & 1.458 .222 & 6.429 .822 \\
\hline Biaya Kemasan & 1.408 .865 & 1.101 .730 & 1.032 .907 & 3.543 .502 \\
\hline Biaya Gas Elpiji & 83.990 & 61.972 & 36.455 & 182.417 \\
\hline Biaya Transportasi & 110.586 & 81.596 & 47.999 & 240.181 \\
\hline Biaya Pulsa Usaha & 12.598 & 9.295 & 5.468 & 27.361 \\
\hline Biaya Listrik & 35.233 & 25.996 & 15.292 & 76.521 \\
\hline Biaya Air (PDAM) & 65.960 & 48.668 & 28.629 & 143.257 \\
\hline Total Biaya Variabel & 11.997 .074 & 4.613.986 & 5.504 .027 & 22.115 .087 \\
\hline Laba Kontribusi & 12.845 .926 & 10.643 .014 & 5.298 .973 & 28.787 .913 \\
\hline \multicolumn{5}{|l|}{ Biaya Tetap } \\
\hline \multicolumn{5}{|l|}{ BOP Tetap : } \\
\hline Gaji Pimpinan & 1.083 .742 & 786.950 & 467.379 & 2.338 .071 \\
\hline Gaji Tenaga Kerja & 4.199 .503 & 3.098 .617 & 1.822 .778 & 9.120 .898 \\
\hline Biaya Pajak Usaha & 20.997 & 15.493 & 9.113 & 45.603 \\
\hline Abnomen Listrik & 5.879 & 4.338 & 2.551 & 12.768 \\
\hline Biaya Penyusutan & 322.420 & 237.899 & 139.945 & 700.264 \\
\hline Abnomen Air (PDAM) & 839 & 619 & 364 & 1.822 \\
\hline Total Biaya Tetap & 5.633 .384 & 4.143.916 & 2.442 .130 & 12.219 .430 \\
\hline Total b.tetap+b.variabel & 17.630 .458 & 8.757 .902 & 7.946 .157 & 34.334 .517 \\
\hline Laba bersih & 7.212 .542 & 6.499 .098 & 2.856 .843 & 16.568 .483 \\
\hline Persentase & $43,53 \%$ & $39,22 \%$ & $17,24 \%$ & \\
\hline
\end{tabular}

UKM Salacca sendiri sudah mencapai keuntungan sebesar 32\%. Tingginya persentase keuntungan yang diperoleh UKM Salacca dipengaruhi oleh beberapa faktor, diantaranya adalah UKM Salacca telah mencapai volume produksi \pm 4.415 bungkus/bulan untuk 3 jenis olahan produk buah salak dan memasarkan produknya di sekitar kota Padangsidimpuan dan dalam mendistribusikan produknya, UKM Salacca telah bekerja sama dengan 16 toko oleh-oleh dan swalayan. Keuntungan atau laba bersih yang diperoleh dari UKM Salacca untuk 3 jenis produk olahan salak adalah sebesar Rp 16.568.483,-. Dan keuntungan yang diperoleh dari Dodol Salak adalah sebesar Rp 7.212.542,-sedangkan keuntungan yang diperoleh dari Kurma Salak adalah sebesar Rp 6.499.098- dan untuk keuntungan yang diperoleh dari Keripik Salak adalah sebesar Rp 2.856.843,-.

\section{b.Titik Impas}

Titik Impas (BEP) adalah suatu keadaan dimana usaha tidak mengalami kentungan ataupun kerugian dan dapat dikatakan pendapatan penjualan sama dengan biaya yang dikeluarkan (Kasmir, 2008). . Dari hasil analisis yang dilakukan, didapatkan hasil penjualan untuk masing-masing produk sudah berada di atas titik impas yang berarti pihak UKM Salacca ini sudah mendapatkan keuntungan dari usaha yang dijalankan selama periode Mei 2018 ini. Dimana besarnya penjualan untuk produksi dodol salak Rp 24.843.000,- untuk produk kurma salak Rp 15.257.000,- serta untuk produk keripik salak Rp 10.803.000,Titik impas UKM Salacca dapat dilihat pada tabel 2 berikut. 
Tabel 2. Titik Impas Pada UKM Salacca Mei 2018

\begin{tabular}{lrrr}
\hline Keterangan & Dodol Salak & Kurma Salak & Keripik Salak \\
\hline Total biaya tetap (Rp) & 5.633 .384 & 4.143 .916 & 2.442 .130 \\
Total biaya variabel (Rp) & 11.997 .074 & 4.613 .986 & 5.504 .027 \\
Biaya variabel/kemasan (Rp) & 6.277 & 3.326 & 6.623 \\
Harga jual kemasan (Rp) & 13.000 & 11.000 & 13.000 \\
Volume penjualan & & & \\
(kemasan) & 1.911 & 1.387 & 831 \\
Penjualan (Rp) & 24.843 .000 & 15.257 .000 & 10.803 .000 \\
Impas kuantitas (kemasan) & 837 & 539 & 382 \\
Impas penjualan (Rp) & 10.833 .430 & 5.919 .880 & 4.844 .260
\end{tabular}

Apabila produk yang terjual pada UKM Salacca berada dibawah nilai tersebut, maka pihak usaha akan mengalami kerugian dan apabila penjualan yang dilakukan usaha berada di atas titik impas maka akan memperoleh keuntungan.

\section{KESIMPULAN}

Dari hasil penelitian tentang "Analisis Usaha Pengolahan Salak Pada UKM Salacca di Kabupaten Tapanuli Selatan Provinsi Sumatera Utara" dapat disimpulkan bahwa :

1. Usaha UKM Salacca dibentuk pada tahun 2014 merupakan usaha kecil yang memproduksi olahan produk dari buah salak padangsidimpuan, berupa dodol salak, kurma salak, keripik salak, minuman salak, sirup salak, madu salak, kecap salak, kopi salak, manisan salak, sari salak dan agar-agar salak. Pada aspek sumberdaya usaha ini memiliki tenaga kerja sebanyak 11 orang termasuk pimpinan usaha dengan sistem gaji (wage) yang dipimpin oleh ibu Sri Lestari, pada aspek peralatan dan mesin usaha ini sudah menggunakan beberapa alat dan mesin yang canggih atau dapat dikatan tidak menggunakan tenaga manual sehingga proses produksi dapat berjalan dengan cepat, pada aspek produksi untuk pengadaan bahan baku UKM Salacca memasok dari petani salak di sekitar daerah tersebut, pada aspek bauran pemasaran untuk mendistribusikan produk ini memiliki saluran distribusi langsung dan tidak langsung, Pada aspek yang terakhir yaitu keuangan usaha ini memiliki sumber modal sendiri, tidak melakukan peminjaman ke bank dan belum melakukan pencatatan akuntansi dengan baik.

2. Keuntungan atau laba bersih yang diperoleh oleh UKM Salacca selama periode Mei 2018 dari ketiga jenis produk yang dihasilkan adalah sebesar Rp. 16.568.483,- atau sekitar 32\%. Keuntungan yang di peroleh dari dodol salak adalah sebesar Rp. 7.212.542,- sedangkan untuk produk kurma salak adalah sebesar Rp. 6.499.098,- dan untuk produk keripik salak adalah sebesar Rp. 2.856.843. Berdasarkan analisis titik impas UKM Salacca periode Mei 2018, maka di peroleh kuantitas titik impas 837 untuk produk dodol salak dan 539 untuk produk kurma salak serta 382 untuk keripik salak. Besarnya nilai penjualan dalam keadaan impas ini adalah Rp. 10.833.430 untuk produk dodol salak, sedangkan untuk produk kurma salak sebesar Rp. 5.919.880,-dan untuk produk keripik salak sebesar Rp. 4.844.260. Pada saat penelitian UKM Salacca sudah berproduksi diatas titik impas, dimana besarnya total pendapatan penjualan untuk produk dodol salak adalah sebesar Rp 24.843.000,- untuk total pendapatan penjualan kurma salak sebesar Rp 15.257.000,- dan untuk total pendapatan keripik salak sebesar Rp 10.803.000,-.

Berdasarkan hasil penelitian yang telah dilakukan, disarankan kepada pemilik UKM Salacca hal-hal sebagai berikut :

1. Dari aspek pemasaran, UKM Salacca diharapkan memperluas kerjasama dengan toko oleh-oleh yang berada di luar kota maupun di luar provinsi Sumatera Utara, agar usaha dapat lebih berkembang dan dikenal banyak orang. 
2. Dari aspek sumberdaya dan peralatan, disarankan kepada pihak UKM Salacca untuk dapat menambah tenaga kerja dan peralatan sehingga dapat lebih maksimal dalam menghasilkan produksi.

3. Dari aspek keuangan, UKM Salacca diharapkan mampu melakukan pencatatan laporan keuangan yang baik dan lebih rinci terkait biaya-biaya yang dikeluarkan selama proses produksi dan juga terkait pendapatan yang diperoleh serta sebaiknya perusahaan dapat melakukan pencatatan laporan keuangan dengan menggunakan pencatatan yang baik. Hal ini bertujuan untuk dapat melihat tingkat perkembangan dari usaha sehingga pihak usaha bisa melakukan perencanaan yang baik untuk kepentingan pengelolaan usaha saat ini maupun untuk di masa yang akan datang.

\section{Daftar Pustaka}

Anoraga. 2009. Manajemen Bisnis. Rineka Cipta. Jakarta.

Badan Pusat Statistik. 2016. Kabupaten Tapanuli Selatan dalam Angka. Kabupaten Tapanuli Selatan.

Departemen Koperasi. Undang-undang No 9 Tahun 1995 Mengenai Usaha Kecil dan Menengah. http://www.depkop.go.id (6 November 2017).

Dinas pertanian. 2016. Dinas Pertanian Tapanuli Selatan. Kabupaten Tapanuli Selatan.

Handoko, T. Hani. 1999. Dasar Dasar Manajemen Produksi dan Operasi. BPFE: Yogyakarta.

Husnan, S dan Suwarsono. 2000. Studi kelayakan Proyek. Rineka Cipta. Unit Penerbit dan Percetakan AMP YKPN. Yogyakarta.

Humas Sumatera Utara. SK Gubsu No. 188.44/575/KPTS/2017 Mengenai UMP. http://humas.sumutprov.go.id

Ibrahim, Y. 2003.Studi Kelayakan Bisnis. Rineka Cipta. Jakarta.

Kotler dan Amstrong. 1997. Prinsip-prinsip Pemasaran. Edisi Ketiga. PT Gelora Aksara Pratama.

Jakarta. 440 hal.

Kotler, P. dan Amstrong, Gerry. 2002. Manajemen Pemasaran. PT Phenhalindo. Jakarta.

Mardikanto, 2007.Pengantar Ilmu Pertanian. Pusat Pengembangan Agrobisnis dan Perhutanan Sosial.

Surakarta.

Martua, Richart. 2015. Analisis Usaha Pengolahan Salak Pada Koperasi Agrina di Kabupaten Tapanuli

Selatan Provinsi Sumatera Utara. Fakultas Pertanian. Universitas Andalas. 126 hal.

Mulyadi. 2009. Akuntansi Biaya. UPP STIM YKPN. Yogyakarta.

Nasrida. 2013. Analisa Usaha Teh Beras Hitam Pada PPO Santiago Nagari Sarik Alahan Tigo

Kecamatan Hiliran Gumanti Kabupaten Solok. Fakultas Pertanian. Universitas Andalas.

Nazir, Moh. 2011. Metode Penelitian. Ghalia Indonesia. Jakarta.

Novilisia. 2016. Analisis Usaha Keripik Ubi Yus Family di Kapuh Sumani Kecamatan X Koto Singkarak

Kabupaten Solok. Fakultas Pertanian. Universitas Andalas.

Octavia, Rithya. 2015. Analisis Usaha Cokelat Goreng Linduang Bulan di Kota Padang. Fakultas

Pertanian. Universitas Andalas.111 hal.

Redaksi Agromedia. 2007. Budidaya Salak. PT Agromedia Pustaka. Jakarta.

Siagian, R. 2003.Pengantar Manajemen Agribisnis. Gadjah Mada University Press. Yogyakarta.

Siagian, R. 2003.Agribisnis Teori dan Aplikasinya.PT Raja Grafindo. Jakarta.

Soekartawi. 2003. Agribisnis Teori dan Aplikasinya.Jakarta: Raja Grafindo Persada.

Soekartawi. 2005. Agroindustri dalam Perspektif Sosial Ekonomi. Jakarta: PT Raja Grafindo Persada.

Subanar, Harimurti. 1994. Manajemen Usaha Kecil. BPFE Universitas Gadjah Mada. Yogyakarta.

Surya, Dani. 2016. Analisis Usaha Kipang H.Anas di Kota Padang. Fakultas Pertanian. Universitas Andalas.116 hal.

Swastha, Bashu dan Sukotjo, Ibnu. 1999. Pengantar Bisnis Modern. Edisi Ketiga. Liberty. Yogyakarta. 